\title{
Biometric and Physiological Quality of Bracatinga Seeds From Different Mother Trees
}

\author{
Renata Diane Menegatti ${ }^{1}$ (D), Adelar Mantovani² (D), Marcio Navroski² (D) \\ ${ }^{1}$ Universidade Federal de Pelotas - UFPEL, Pelotas/RS, Brasil \\ ${ }^{2}$ Universidade do Estado de Santa Catarina - UDESC, Lages/SC, Brasil
}

\begin{abstract}
Mimosa scabrella Bentham (bracatinga) is a prominent forest species in the south of the country, due mainly to the high rate of increase, rapid development cycle, and to enable multiple uses of wood production, both for firewood and for more noble purposes. The aim of this work was to estimate the physiological variation among 40 mother trees, based on germinative and biometric characterization of seeds and seedlings. Biometric traits were determined for the size and the fresh mass of 100 seeds, percentage of germination and normal seedlings, germination velocity index, daily mean germination, length, and dry mass of seedlings. Means were compared by the Scott-Knott test at $1 \%$ probability and estimates of Pearson correlation coefficients were obtained between all traits. The results indicate the existence of significant variation between arrays of same or different origin for both the biometric features as those from the germination test. The physiological quality of the seeds showed no direct relation to its size.
\end{abstract}

Keywords: bracatinga, physiological potential, forest seeds. 


\section{INTRODUCTION}

Mimosa scabrella Benth. is a native forest species to the southern region of Brazil, belonging to the Fabaceae family and popularly known as bracatinga. Specie of rapid growth, average annual increment of approximately $24 \mathrm{~m}^{3} / \mathrm{ha} /$ year (Sánchez et al., 2010) and which can reach $18 \mathrm{~m}$ in height, with a shaft of up to $40 \mathrm{~cm}$ in diameter at breast height (Carvalho, 2003). Recently, this species has been prioritized in broad spectrum research in southern Brazil, due to its economic importance and relevant energy capacity, similar, or even superior, that of some species of the genera Eucalyptus (Mazuchowski \& Angelo, 2012; Mazuchowski et al., 2014; Friederichs et al., 2015; Menegatti et al., 2017).

Because it is an undomesticated species, its large-scale use in homogeneous forest plantations still has limitations. Within these limits, what stands the little knowledge about the genetic variability existing among the natural populations of occurrence of the species, this information is needed to initiate the programs of genetic improvement for characters of interest (Borém \& Miranda, 2009).

Such as Carvalho \& Nakagawa (2000), the importance of working with seeds from geographically distinct localities is related to the possibility of finding genetic differences within the species, as well as the phenotypic differences determined by environmental variations. Knowing the natural variability, one can select individuals or materials that gather superior characteristics, and thus provide information of potential parents to be used in improvement programs (Borém \& Miranda, 2009).

Some works have already been carried out in order to describe the genetic variability present in the natural populations of M. Scabrella, by means of isozymes electrophoresis (Sobierajski et al., 2006; Moreira et al., 2011); however, these analyses are spent on thorough techniques requiring long periods for realization. Studies focusing on the biometric characterization of seeds are rare, however, of easy and rapid realization, and serve as indicative of the genetic variability available to be exploited (Carvalho \& Nakagawa, 2000; Guollo et al., 2016).

The analysis of differences in different dimensions of seeds, known as seeds biometry, has been used in different native species of Brazil, such as Mucuna aterrima (Piper \& Tracy) Holland (Abud et al., 2009), Dimorphandra mollis Benth. (Freitas et al., 2009), Plathymenia reticulata Benth. and Plathymenia foliolosa Benth. (Lopes et al., 2010), Melanoxylon brauna Schott (Silva et al., 2013), and Calotropis procera Aiton (Oliveira-Bento et al., 2013). Biometric analyzes when carried out concomitantly to germination testing, it allows us to infer superiority in the physiological quality and to capture variations among individuals and populations when we evaluate material from different procedures (Carvalho \& Nakagawa, 2000).

The high genetic variability within a single species, mainly those they are not domesticated, it has been related with the variation of the seeds size, as well as in the difference germinative capacity of seeds, and this relationship has been strongly observed in native species of Brazil (Santos et al., 2009). It is known that the seedling production stage is fundamental to the success of a forest enterprise, and this depends mainly on the physiological quality of the seeds, which is usually evaluated from the standard germination test (Brasil, 2013), being the germinative capacity one of the main factors to be considered, since it can directly affect the vigor and the quality of the seedlings.

Popinigis (1985) suggests the use of biometric analyzes, that is, differences in seed size as indicative of the physiological quality, but some authors have found controversial results, that is, and they did not observed a relation between seed size and the physiological quality of seeds (Sturion, 1984; Santos et al., 2009). The existence of this relationship is an important factor for seedling producers, since they could use seed size as indicators of the physiological performance in germination.

In view of the above, this study aimed to estimate physiological variations among 40 mother trees of M. scabrella Benth. from four municipalities in the state of Santa Catarina, Brazil, based on germinative studies and biometric characteristics of seeds and seedlings.

\section{MATERIAL AND METHODS}

The seeds of M. scabrella were obtained from fruits in an similar maturation stage, that is, collected in a standardized way when they were at the beginning of dehiscence, presenting a light brown color 
(Mazuchowski et al., 2014), which occurred in December 2013. The fruits were harvested with a pruning shear in 40 mother trees (Table 1), in four provenances belonging to Santa Catarina, namely: Abelardo Luz, Chapadão do Lageado, Lages, and Três Barras, being 10 mother trees in each site.

The choice of the mother trees was based upon recommendations prescribed by Sebbenn (2006) obeying the minimal distance of $100 \mathrm{~m}$ between the trees, aiming to decrease the possibility of sampling related individuals.

Next, the fruits of each mother tree were stored in paper boxes and kept under laboratory conditions during the 7 day's period to force the natural opening and aid in the later extraction of seeds, stored in polyethylene bags at ambient temperature, and taken to the Forest Ecology Laboratory of the Agroveterinary Science Center of the Santa Catarina State University (Udesc), localized at Lages, for immediately utilized in the conduction of the experiment.

Biometric analyzes and seed germination tests were performed separately for each mother tree, using a completely randomized experimental design, with four replicates of 25 seeds for each analysis.

For the biometric analyzes, the determined dimensions were length (LS), breadth (BS), and thickness (TS) of seeds, besides the fresh mass of 100 seeds (FM100S). The determined dimensions was obtained with the use of a digital pachymeter $(0.01 \mathrm{~mm})$, and the mass of balance seeds was weighted with the utilization of an analytical balance (precision of $0.0001 \mathrm{~g}$ ).

For the germination test, firstly break of dormancy of seeds by the method of immersion into the water at the initial temperature of $80{ }^{\circ} \mathrm{C}$ was performed, followed by rest in the same water out of the heating for 18 hours (Brasil, 2013). Soon afterward, the seeds were placed under germitest paper rolls, wetted with water equivalent to 2.5 times the weight of the substrate with three sheets per roll. The paper rolls were identified and incubated in type Biological Oxygen Demand (B.O.D.) oven containing three fluorescent lamps of $15 \mathrm{~W}$ and 12 hours photoperiod at a constant temperature of $25^{\circ} \mathrm{C}$, according to the instructions for forest species analysis (Brasil, 2013).

The seeds germination was evaluated daily, considering seeds germinated as those which presented the radical protrusion of at least $2 \mathrm{~mm}$ in length and normal seedling formation (Brasil, 2013). At the end of the test, of the duration of 8 days, were determined: \% of germination (\%GER) - percentage relation between the number of seeds germinated and the total number of seeds; germination velocity index (GVI) - result of the sum of the daily germination ratio by time, in days, after the beginning of the test; mean diary germination (MDG) - obtained by the ratio between number total germinated seeds and the number of days of germination test duration; \% of normal seedlings (\%NS) - percentage relation between the number of seedlings with the perfect essential structures in relation to the number total of seedlings; length normal seedlings (LNS) - evaluated in all normal seedlings of each replicate/treatment, obtained with the use of a digital pachymeter $(0.01 \mathrm{~mm})$; and dry mass of the seedlings (DMS) - determined from cotyledons removal from normal seedlings that were subsequently dried in an oven regulated at $80^{\circ} \mathrm{C}$ for 24 hours and weighed on analytical balance (precision of $0.0001 \mathrm{~g}$ ).

The variables of the biometrics, germination percentage, germination speed index, and percentage of normal seedlings, as they did not show normality, were transformed to $(\mathrm{X} / 100)^{0.5}$. Once meet to normality and homoscedasticity, statistical analyzes were performed for the biometric and physiological quality characteristics, both arranged in a completely randomized design, with four replicates of 25 seeds. The comparison of means between treatments was

Table 1. Provenances, geographical coordinates, and average altitude of 40 mother trees of Mimosa scabrella Benth. sampled in the Santa Catarina state (Brazil).

\begin{tabular}{ccccc|} 
Mother trees & Provenances & $\begin{array}{c}\text { Latitude } \\
(\mathbf{S})\end{array}$ & $\begin{array}{c}\text { Longitude } \\
(\mathbf{O})\end{array}$ & $\begin{array}{c}\text { Average altitude } \\
(\mathbf{m})\end{array}$ \\
\hline $1-10$ & Abelardo Luz & $36^{\circ} 74^{\prime} 49^{\prime \prime}$ & $70^{\circ} 71^{\prime} 49^{\prime \prime}$ & 760 \\
$11-20$ & Chapadão do Lageado & $64^{\circ} 19^{\prime} 50^{\prime \prime}$ & $69^{\circ} 46^{\prime} 43^{\prime \prime}$ & 570 \\
\hline $21-30$ & Lages & $57^{\circ} 51^{\prime} 23^{\prime \prime}$ & $69^{\circ} 21^{\prime} 31^{\prime \prime}$ & 884 \\
\hline $31-40$ & Três Barras & $56^{\circ} 97^{\prime} 22^{\prime \prime}$ & $70^{\circ} 97^{\prime} 41^{\prime \prime}$ & 802 \\
\hline
\end{tabular}


performed by the Scott-Knott test at $1 \%$ probability. In addition, estimates of Pearson correlation coefficients were obtained among all evaluated characteristics.

\section{RESULTS AND DISCUSSION}

Likewise, the analysis of variance it was possible to infer that there were significant statistical differences ( $\mathrm{p} \leq 0.01$ ) among the 40 mother trees of M. scabrella, for all the biometric variables evaluated: length, breadth, thickness, and fresh weight of 100 seeds (Table 2).

The observed variations in the biometric characteristics may be associated to the physiological maturity of the seeds, as well as genetic and/or microenvironmental factors of the place of development of the mother trees, since, with objective in order to evaluate the variability maximum of the specie, the sampling prioritized to encompass extreme provenances within the region of occurrence in Santa Catarina. Results similar to the present study were obtained by Santos et al. (2009) in works carried out with seeds of different mother tress of Tabebuia chrysotricha and Corymbia citriodora, suggesting that seeds of different mother trees of the same species may present differences in their dimensions and which these characteristics when related to physiological quality could be used as indicative of seed quality of this specie, aiming to obtain higher percentages of germinated seeds, seedlings with greater vigor, and seedlings of better quality.

The coefficient of variation obtained is considered low $(<10 \%)$ for all variables, confirming that for these characteristics a certain uniformity among the seeds occurs. Similar results were observed in other species of the same family (Fabaceae), such as, for example, for Valadares et al. (2009) and Nogueira et al. (2010), in biometric characterization studies of Poecilanthe parviflora Benth. and Dalbergia cearensis Ducke, respectively.

By means of the means comparison test (Scott-Knott) (Table 2), it was possible to verify the formation of a large number of groups, mainly for the FM100S variable, suggesting a greater variability for this characteristic among the sampled materials. For the FM100S characteristic, 11 groups of averages were formed, varying from $0.9626 \mathrm{~g}$ (mother tree 17) to $1.7208 \mathrm{~g}$ (mother tree 40).
The variation presented by for the FM100S characteristic between the mother trees indicates that the evaluated seeds may be in different stages of physiological maturation, as the maturation is a slow process that varies between trees of the same species and in the same tree, according to the position of the fruit in the same (Figliolia, 1995). Just as Carvalho \& Nakagawa (2000), the physiological maturity of the seeds occurs accompanied by the morphological, physiological, and functional changes, among them, the variation in the color of the fruits, the size of the seeds, and others.

For the variable BS have been formed nine groups ranging from $2.86 \mathrm{~mm}$ (mother tree 37 ) to $3.84 \mathrm{~mm}$ (mother tree 16). For LS and TS of seeds, eight groups were formed, ranging from $4.29 \mathrm{~mm}$ (mother tree 7) to $5.87 \mathrm{~mm}$ (mother tree 25), and for seed thickness the means varied of $1.11 \mathrm{~mm}$ (mother tree 13) at $1.57 \mathrm{~mm}$ (mother tree 40). The expressive number of groups formed for these characteristics shows the variability in the seed size of the different matrix trees.

According with Table 2, the Lages mother tree 25 showed higher seed length, but was among those with showed inferior values of width. Since the mother tree 16, from Chapadão do Lageado, deserves to be highlighted because it presents a larger seed width, however, for the parameter length of seeds it is located in the third group formed from the comparison test of means. For seed thickness and FM100S stands out the mother tree 40 , from Três Barras, this same matrix presents intermediate values for length and width.

The results of the analysis of variance and the means referring to the characteristics evaluated in the germination test are presented in Table 3. Estimates of the coefficients of experimental variation ranged from $14.26 \%$ for germination (\%GER) and MDG, up to $21.94 \%$ DMS.

Seven groups of mother trees were formed based on mean germination values (Table 3 ). Seven matrices represented the first group (upper), three of them belong to Abelardo Luz (M4, M6, and M10), and the others to Chapadão do Lageado (M12, M15, M17, and M20), with mean values varying from 95 to $98 \%$ (M10 and M17).

On the second group, 10 mother trees were identified, with germination values ranging from 81\% (M38 and M39) to 89\% (M19); the Abelardo Luz 
Table 2. Variance analysis summary and test comparison of averages for length (LS), breadth (BS), and thickness (TS) of seeds and fresh mass of 100 seeds (FM100S in g) of Mimosa scabrella Benth. from different mother trees collected in the municipalities of Abelardo Luz, Chapadão do Lageado, Lages and Três Barras, Santa Catarina state (Brazil).

\begin{tabular}{|c|c|c|c|c|}
\hline \multirow{2}{*}{ Source of variation } & \multicolumn{4}{|c|}{ Mean Square } \\
\hline & LS & BS & TS & FM100S \\
\hline Mother trees & $0.29^{* *}$ & $0.20^{* *}$ & $0.06^{\star *}$ & $0.2511^{\star *}$ \\
\hline Residue & 0.006 & 0.003 & 0.002 & 0.0022 \\
\hline Mean & 4.98 & 3.42 & 1.33 & 1.3443 \\
\hline $\mathrm{CV}(\%)$ & 1.54 & 1.81 & 3.34 & 3.5412 \\
\hline Mother tree & \multicolumn{4}{|c|}{ Means } \\
\hline 1 & $5.06 \mathrm{~d}$ & $3.65 \mathrm{~b}$ & $1.38 \mathrm{~d}$ & $1.4125 \mathrm{~d}$ \\
\hline 2 & $4.91 \mathrm{e}$ & $3.13 \mathrm{~h}$ & $1.53 \mathrm{a}$ & $1.0629 \mathrm{j}$ \\
\hline 3 & $4.86 \mathrm{e}$ & $3.49 \mathrm{~d}$ & $1.42 \mathrm{c}$ & $1.2325 \mathrm{~h}$ \\
\hline 4 & $5.06 \mathrm{~d}$ & $3.65 \mathrm{~b}$ & $1.38 \mathrm{~d}$ & $1.1348 \mathrm{i}$ \\
\hline 5 & $4.61 \mathrm{~g}$ & $3.31 \mathrm{f}$ & $1.23 \mathrm{~g}$ & $1.5291 \mathrm{~b}$ \\
\hline 6 & $5.06 \mathrm{~d}$ & $3.62 \mathrm{~b}$ & $1.49 \mathrm{~b}$ & $1.3704 \mathrm{e}$ \\
\hline 7 & $4.29 \mathrm{~h}$ & $3.09 \mathrm{~h}$ & $1.25 \mathrm{~g}$ & $1.3101 \mathrm{~g}$ \\
\hline 8 & $4.76 \mathrm{f}$ & $3.37 \mathrm{f}$ & $1.19 \mathrm{~g}$ & $1.2977 \mathrm{~g}$ \\
\hline 9 & $4.65 \mathrm{~g}$ & $3.23 \mathrm{~g}$ & $1.23 \mathrm{~g}$ & $1.1856 \mathrm{~h}$ \\
\hline 10 & $5.11 \mathrm{~d}$ & $3.15 \mathrm{~h}$ & $1.55 \mathrm{a}$ & $1.3890 \mathrm{e}$ \\
\hline 11 & $5.24 \mathrm{c}$ & $3.24 \mathrm{~g}$ & $1.34 \mathrm{e}$ & $1.5048 \mathrm{c}$ \\
\hline 12 & $4.62 \mathrm{~g}$ & $3.21 \mathrm{~g}$ & $1.21 \mathrm{~g}$ & $1.4436 \mathrm{~d}$ \\
\hline 13 & $4.86 \mathrm{e}$ & $3.70 \mathrm{~b}$ & $1.11 \mathrm{~h}$ & $1.4879 \mathrm{c}$ \\
\hline 14 & $5.07 \mathrm{~d}$ & $3.22 \mathrm{~g}$ & $1.24 \mathrm{~g}$ & $1.5094 \mathrm{c}$ \\
\hline 15 & $4.93 \mathrm{e}$ & $3.83 \mathrm{a}$ & $1.14 \mathrm{~h}$ & $1.1325 \mathrm{i}$ \\
\hline 16 & $5.15 \mathrm{c}$ & $3.84 \mathrm{a}$ & $1.24 \mathrm{~g}$ & $1.5679 \mathrm{~b}$ \\
\hline 17 & $5.23 c$ & $3.38 \mathrm{f}$ & $1.22 \mathrm{~g}$ & 0.96261 \\
\hline 18 & $4.78 \mathrm{f}$ & $3.56 \mathrm{c}$ & $1.21 \mathrm{~g}$ & $1.2141 \mathrm{~h}$ \\
\hline 19 & $4.84 \mathrm{e}$ & $3.38 \mathrm{f}$ & $1.26 \mathrm{f}$ & $1.1329 \mathrm{i}$ \\
\hline 20 & $5.14 \mathrm{c}$ & $3.09 \mathrm{~h}$ & $1.45 \mathrm{c}$ & $1.4407 \mathrm{~d}$ \\
\hline 21 & $4.90 \mathrm{e}$ & $3.59 \mathrm{c}$ & $1.54 \mathrm{a}$ & $1.3343 \mathrm{f}$ \\
\hline 22 & $5.20 \mathrm{c}$ & $3.52 \mathrm{c}$ & $1.26 \mathrm{f}$ & $1.2286 \mathrm{~h}$ \\
\hline 23 & $4.70 \mathrm{f}$ & $3.33 \mathrm{f}$ & $1.33 \mathrm{e}$ & $1.2588 \mathrm{~g}$ \\
\hline 24 & $4.86 \mathrm{e}$ & $3.59 \mathrm{c}$ & $1.19 \mathrm{~g}$ & $1.3927 \mathrm{e}$ \\
\hline 25 & $5.87 \mathrm{a}$ & $3.08 \mathrm{~h}$ & $1.43 \mathrm{c}$ & $1.4771 \mathrm{c}$ \\
\hline 26 & $5.28 \mathrm{c}$ & $3.29 \mathrm{f}$ & $1.32 \mathrm{e}$ & $1.2697 \mathrm{~g}$ \\
\hline 27 & $5.16 \mathrm{c}$ & $3.41 \mathrm{e}$ & $1.36 \mathrm{~d}$ & 0.98171 \\
\hline 28 & $5.05 \mathrm{~d}$ & $3.19 \mathrm{~g}$ & $1.33 \mathrm{e}$ & $1.2933 \mathrm{~g}$ \\
\hline 29 & $5.21 \mathrm{c}$ & $3.77 \mathrm{a}$ & $1.23 \mathrm{~g}$ & $1.5225 \mathrm{~b}$ \\
\hline 30 & $5.50 \mathrm{~b}$ & $3.27 \mathrm{~g}$ & $1.51 \mathrm{~b}$ & $1.5730 \mathrm{~b}$ \\
\hline 31 & $4.99 \mathrm{~d}$ & $3.65 \mathrm{~b}$ & $1.31 \mathrm{e}$ & $1.5740 \mathrm{~b}$ \\
\hline 32 & $4.81 \mathrm{f}$ & $3.58 \mathrm{c}$ & $1.21 \mathrm{~g}$ & $1.4293 \mathrm{~d}$ \\
\hline 33 & $4.71 \mathrm{f}$ & $3.49 \mathrm{~d}$ & $1.22 \mathrm{~g}$ & $1.1199 \mathrm{i}$ \\
\hline 34 & $5.05 \mathrm{~d}$ & $3.43 \mathrm{e}$ & $1.40 \mathrm{~d}$ & $1.2554 \mathrm{~g}$ \\
\hline 35 & $5.12 \mathrm{~d}$ & $3.50 \mathrm{~d}$ & $1.46 \mathrm{~b}$ & $1.5312 \mathrm{~b}$ \\
\hline 36 & $4.77 \mathrm{f}$ & $3.42 \mathrm{e}$ & $1.29 \mathrm{f}$ & $1.3413 \mathrm{f}$ \\
\hline 37 & $4.90 \mathrm{e}$ & $2.86 \mathrm{i}$ & $1.16 \mathrm{~h}$ & $1.3769 \mathrm{e}$ \\
\hline 38 & $4.82 \mathrm{e}$ & $3.52 \mathrm{c}$ & $1.36 \mathrm{~d}$ & $1.1909 \mathrm{~h}$ \\
\hline 39 & $5.12 \mathrm{~d}$ & $3.59 c$ & $1.48 \mathrm{~b}$ & $1.5529 \mathrm{~b}$ \\
\hline 40 & $5.01 \mathrm{~d}$ & $3.56 c$ & $1.57 \mathrm{a}$ & $1.7208 \mathrm{a}$ \\
\hline
\end{tabular}

${ }^{*}$ Significant $(\mathrm{p} \leq 0.01)$ by the test F. Means followed by the same letter do not differ among themselves by the Scott-Knott test at 1\% probability. Provenances of the mother trees: 1-10 Abelardo Luz; 11-20 Chapadão do Lageado; 21-30 Lages; 31-40 Três Barras; $\mathrm{CV}=$ coefficient of variation . 
Table 3. Variance analysis summary for germination percentage (\%GER), germination velocity index (GVI), mean diary germination (MDG), percentage of normal seedlings (\%PN), length normal seedlings (LNS in $\mathrm{cm}$ ), and dry mass of the seedling (DMS in g) of Mimosa scabrella Benth. from different mother trees, the municipalities of Abelardo Luz, Chapadão do Lageado, Lages, and Três Barras, Santa Catarina state (Brazil).

\begin{tabular}{|c|c|c|c|c|c|c|}
\hline \multirow{2}{*}{$\begin{array}{l}\text { Source of } \\
\text { variation }\end{array}$} & \multicolumn{6}{|c|}{ Mean Square } \\
\hline & \%GER & GVI & MDG & $\% \mathbf{P N}$ & LNS & DMS \\
\hline Mother trees & $3171.60^{* *}$ & $205.17^{\star *}$ & $3.09^{* *}$ & $199.05^{\star *}$ & $12.96^{* *}$ & $1.31^{\star *}$ \\
\hline Residue & 78.53 & 2.87 & 0.08 & 5.34 & 4.43 & 0.06 \\
\hline Mean & 62.15 & 11.03 & 1.94 & 55.8 & 11.09 & 1.08 \\
\hline CV (\%) & 14.26 & 15.35 & 14.26 & 16.56 & 18.97 & 21.94 \\
\hline Mother tree & \multicolumn{6}{|c|}{ Means } \\
\hline 1 & $44.00 \mathrm{f}$ & $5.19 \mathrm{f}$ & $1.50 \mathrm{~d}$ & $28 \mathrm{f}$ & $11.07 \mathrm{~b}$ & $0.86 \mathrm{~d}$ \\
\hline 2 & $85.00 \mathrm{~b}$ & $19.20 \mathrm{~b}$ & $3.03 \mathrm{a}$ & $81 \mathrm{~b}$ & $12.98 \mathrm{a}$ & $1.60 \mathrm{~b}$ \\
\hline 3 & $84.00 \mathrm{~b}$ & $19.04 \mathrm{~b}$ & $0.69 \mathrm{~g}$ & $74 \mathrm{c}$ & $14.42 \mathrm{a}$ & $1.73 \mathrm{~b}$ \\
\hline 4 & $95.00 \mathrm{a}$ & $20.26 \mathrm{~b}$ & $0.72 \mathrm{~g}$ & $85 \mathrm{~b}$ & $13.70 \mathrm{a}$ & $1.40 \mathrm{c}$ \\
\hline 5 & $82.00 \mathrm{~b}$ & $18.23 \mathrm{~b}$ & $2.91 \mathrm{a}$ & $77 \mathrm{~b}$ & $10.44 \mathrm{a}$ & $1.32 \mathrm{c}$ \\
\hline 6 & $96.00 \mathrm{a}$ & $22.01 \mathrm{a}$ & $1.03 \mathrm{f}$ & $93 a$ & $14.85 \mathrm{a}$ & $1.77 \mathrm{~b}$ \\
\hline 7 & $40.00 \mathrm{e}$ & $3.91 \mathrm{f}$ & $3.06 \mathrm{a}$ & $34 \mathrm{f}$ & $12.34 \mathrm{a}$ & $0.52 \mathrm{e}$ \\
\hline 8 & $42.00 \mathrm{e}$ & $6.47 \mathrm{e}$ & $2.22 \mathrm{c}$ & $34 \mathrm{f}$ & $9.97 \mathrm{~b}$ & $0.64 \mathrm{~d}$ \\
\hline 9 & $84.00 \mathrm{~b}$ & $19.01 \mathrm{~b}$ & $2.78 \mathrm{~b}$ & $80 \mathrm{~b}$ & $10.73 \mathrm{~b}$ & $1.07 \mathrm{c}$ \\
\hline 10 & $98.00 \mathrm{a}$ & $22.60 \mathrm{a}$ & $3.03 \mathrm{a}$ & $91 \mathrm{a}$ & $13.73 \mathrm{a}$ & $2.04 \mathrm{a}$ \\
\hline 11 & $48.00 \mathrm{~d}$ & $3.96 \mathrm{f}$ & $1.06 \mathrm{f}$ & $35 \mathrm{f}$ & $9.89 \mathrm{~b}$ & $0.70 \mathrm{~d}$ \\
\hline 12 & $97.00 \mathrm{a}$ & $21.35 \mathrm{a}$ & $2.66 \mathrm{~b}$ & $95 a$ & $10.94 \mathrm{~b}$ & $1.43 \mathrm{c}$ \\
\hline 13 & $22.00 \mathrm{~g}$ & $1.96 \mathrm{f}$ & $2.62 \mathrm{~b}$ & $16 \mathrm{~g}$ & $8.76 \mathrm{~b}$ & $0.27 \mathrm{e}$ \\
\hline 14 & $23.00 \mathrm{~g}$ & $3.66 \mathrm{f}$ & $2.97 \mathrm{a}$ & $23 \mathrm{~g}$ & $10.14 b$ & $0.40 \mathrm{e}$ \\
\hline 15 & $93.00 \mathrm{a}$ & $18.96 \mathrm{~b}$ & $2.56 \mathrm{~b}$ & $90 a$ & $13.77 \mathrm{a}$ & $2.12 \mathrm{a}$ \\
\hline 16 & $33.00 \mathrm{f}$ & $3.84 \mathrm{f}$ & $3.00 \mathrm{a}$ & $26 \mathrm{f}$ & $6.74 \mathrm{~b}$ & $0.45 \mathrm{e}$ \\
\hline 17 & $98.00 \mathrm{a}$ & $21.60 \mathrm{a}$ & $1.25 \mathrm{e}$ & $94 \mathrm{a}$ & $12.68 \mathrm{a}$ & $1.84 \mathrm{~b}$ \\
\hline 18 & $71.00 \mathrm{c}$ & $10.74 \mathrm{~d}$ & $1.31 \mathrm{e}$ & $56 \mathrm{~d}$ & $9.75 \mathrm{~b}$ & $0.99 \mathrm{~d}$ \\
\hline 19 & $89.00 \mathrm{~b}$ & $13.61 \mathrm{c}$ & $2.62 \mathrm{~b}$ & $83 \mathrm{~b}$ & $11.81 \mathrm{a}$ & $1.50 \mathrm{c}$ \\
\hline 20 & $97.00 \mathrm{a}$ & $11.89 \mathrm{c}$ & $3.06 \mathrm{a}$ & $89 a$ & $12.67 \mathrm{a}$ & $1.69 \mathrm{~b}$ \\
\hline 21 & $17.00 \mathrm{~g}$ & $1.94 \mathrm{f}$ & $2.25 c$ & $12 \mathrm{~g}$ & $9.89 \mathrm{~b}$ & $0.26 \mathrm{e}$ \\
\hline 22 & $86.00 \mathrm{~b}$ & $18.00 \mathrm{~b}$ & $1.03 \mathrm{f}$ & $75 \mathrm{c}$ & $12.14 \mathrm{a}$ & $1.33 \mathrm{c}$ \\
\hline 23 & $88.00 \mathrm{~b}$ & $19.98 \mathrm{~b}$ & $0.75 \mathrm{~g}$ & $84 \mathrm{~b}$ & $11.83 \mathrm{a}$ & $1.47 \mathrm{c}$ \\
\hline 24 & $83.00 \mathrm{~b}$ & $18.61 \mathrm{~b}$ & $2.31 \mathrm{c}$ & $80 \mathrm{~b}$ & $13.69 \mathrm{a}$ & $1.83 \mathrm{~b}$ \\
\hline 25 & $74.00 \mathrm{c}$ & $12.09 \mathrm{c}$ & $1.03 \mathrm{f}$ & $68 c$ & $11.48 \mathrm{a}$ & $1.43 c$ \\
\hline 26 & $16.00 \mathrm{~g}$ & $2.31 \mathrm{f}$ & $1.78 \mathrm{~d}$ & $14 \mathrm{~g}$ & $8.89 \mathrm{~b}$ & $0.34 \mathrm{e}$ \\
\hline 27 & $30.00 \mathrm{f}$ & $3.63 \mathrm{f}$ & $0.87 \mathrm{f}$ & $22 \mathrm{~g}$ & $8.06 \mathrm{~b}$ & $0.42 \mathrm{e}$ \\
\hline 28 & $52.00 \mathrm{~d}$ & $7.95 \mathrm{e}$ & $2.53 \mathrm{~b}$ & $30 \mathrm{f}$ & $10.90 \mathrm{~b}$ & $0.75 \mathrm{~d}$ \\
\hline 29 & $20.00 \mathrm{~g}$ & $2.51 \mathrm{f}$ & $2.53 \mathrm{~b}$ & $14 \mathrm{~g}$ & $10.10 \mathrm{~b}$ & $0.35 \mathrm{e}$ \\
\hline 30 & $62.00 \mathrm{c}$ & $6.97 \mathrm{e}$ & $2.00 \mathrm{c}$ & $54 \mathrm{~d}$ & $10.30 \mathrm{~b}$ & $1.30 \mathrm{c}$ \\
\hline 31 & $72.00 \mathrm{c}$ & $13.75 \mathrm{c}$ & $0.53 \mathrm{~g}$ & $25 \mathrm{c}$ & $11.27 \mathrm{~b}$ & $1.38 \mathrm{c}$ \\
\hline 32 & $43.00 \mathrm{f}$ & $4.18 \mathrm{f}$ & $2.69 \mathrm{~b}$ & $30 \mathrm{f}$ & $9.25 \mathrm{~b}$ & $0.73 \mathrm{~d}$ \\
\hline 33 & $44.00 \mathrm{~g}$ & $3.27 \mathrm{f}$ & $2.75 \mathrm{~b}$ & $23 \mathrm{~g}$ & $11.00 \mathrm{~b}$ & $0.73 \mathrm{~d}$ \\
\hline 34 & $74.00 \mathrm{c}$ & $7.68 \mathrm{e}$ & $2.60 \mathrm{~b}$ & $68 c$ & $11.59 \mathrm{a}$ & $1.27 \mathrm{c}$ \\
\hline 35 & $33.00 \mathrm{f}$ & $4.22 \mathrm{f}$ & $2.31 \mathrm{c}$ & $30 \mathrm{f}$ & $9.09 \mathrm{~b}$ & $0.43 \mathrm{e}$ \\
\hline 36 & $57.00 \mathrm{~d}$ & $6.07 \mathrm{e}$ & $0.50 \mathrm{~g}$ & $48 \mathrm{e}$ & $10.26 \mathrm{~b}$ & $0.82 \mathrm{~d}$ \\
\hline 37 & $28.00 \mathrm{f}$ & $3.02 \mathrm{f}$ & $0.94 \mathrm{f}$ & $20 \mathrm{~g}$ & $9.81 \mathrm{~b}$ & $0.36 \mathrm{e}$ \\
\hline 38 & $81.00 \mathrm{~b}$ & $13.55 \mathrm{c}$ & $1.62 \mathrm{~d}$ & $69 c$ & $12.33 \mathrm{a}$ & $1.49 \mathrm{c}$ \\
\hline 39 & $81.00 \mathrm{~b}$ & $14.68 \mathrm{c}$ & $0.62 \mathrm{~g}$ & $77 \mathrm{~b}$ & $9.76 \mathrm{~b}$ & $1.71 \mathrm{~b}$ \\
\hline 40 & $64.00 \mathrm{c}$ & $9.49 \mathrm{~d}$ & $1.94 \mathrm{c}$ & $60 \mathrm{~d}$ & $10.62 \mathrm{~b}$ & $1.19 \mathrm{c}$ \\
\hline
\end{tabular}

${ }^{*}$ Significant $(\mathrm{p} \leq 0.01)$ by the test F. Means followed by the same letter do not differ among themselves by the Scott-Knott test at 1\% probability. Provenances of the mother trees: 1-10 Abelardo Luz; 11-20 Chapadão do Lageado; 21-30 Lages; 31-40 Três Barras; $\mathrm{CV}=$ coefficient of variation. 
provenance was the most representative, covering four of them (M2, M3, M5, and M9), only a mother tree belonging to Chapadão do Lageado (M19), three of them from Lages (M22, M23, and M24) and the others from Três Barras (M38 and M39).

For the GVI, MDG, and percentage of normal seedlings (\%PN) were formed six distinct groups, and for the three characteristics, the first groups formed were composed only of mother tree from the provenances of Abelardo Luz and Chapadão do Lageado. The GVI for the four matrices that constituted the first group (M6, M10, M12, and M17) ranged from 21.35 (M12) to 22.60 (M10).

The first group, formed for the daily mean germination characteristic, was consisted of seven mother trees, four of them from Abelardo Luz (M2, M5, M7, and M10) and three mother trees of Chapadão do Lageado (M14, M16, and M20). For this parameter (DMG), the values varied from 2.91 (M5) to 3.06 (M7 and M20). As for the variable percentage of normal seedlings, the first group was represented by six mother trees: two of Abelardo Luz (M6 and M10) and four of Chapadão de Lageado (M12, M15, M17, and M20), with \%PN ranging from $89 \%$ (M 2O) to $95 \%$ (M 12).

The means of LNS were divided into two groups of mother trees (Table 3). The seedlings of the highest means formed the first group consisted of 17 mother trees, most of them from Abelardo Luz, with LNS ranging from 10.44 up to 14.85 . The variable DMS was divided into five groups and represented by two mother trees in the formation of the first group, with one mother tree belonging to Abelardo Luz (M10, with $2.04 \mathrm{~g}$ ) and another to Chapadão do Lageado (M15, $2.12 \mathrm{~g}$ ).

The mother tree 10 of the Abelardo Luz provenance presented higher physiological quality of the seeds considering all the studied variables, presenting a mean of $98 \%$ germination in the test performed and $91 \%$ of normal seedlings, thus presenting a superior performance to the others.

The mother tree 2 of Abelardo Luz and the 15 of Chapadão do Lageado can be considered as high performance, since for all studied variables, their means are always distributed in the first two groups by of the means comparison test. Also worthy of note are the matrices which, in the set of variables studied, presented mean values, and their averages represented in the first three groups formed by the Scott-Knott test, being: M5 and M9 of Abelardo Luz, M12, M19, and M20 of Chapadão do Lageado, and M24 of Lages.

The mother tree 13,14, and 16 of the Chapadão do Lageado provenance, the mother trees $21,26,27$, and 29 from Lages and the mother trees 35 and 37 from Três Barras were classified as of lower physiological quality, according with the results obtained for all the variables from the germination test.

The low percentage of germination indicates the possibility of occurrence of immature seeds in the sample of these mother trees; in many cases, it can be attributed to the time necessary for the dehiscence of the fruits after collection, considering that in some individuals the majority of the fruits were open after 2 days while others had the most of the fruits open on the 7th day. Another fact observed for the afore mentioned mother trees is that the fresh seed mass was the lowest among the matrices (Table 2), indicating a small quantity of reserves and justifying its inferior performance in the tests performed.

According to Carvalho \& Nakagawa (2000), the physiological variability present among seeds of different mother trees may be a consequence of environmental conditions during seed development, or may reflect characteristics of the genetic material itself, or still may be due to the maturation stage of the seeds at the time of collection, which will influence the physiological quality exhibited in the germination test.

Therefore, it is possible to recognize the importance of the variability existing among individuals of the same population in the different places of natural occurrence (provenances), because these differences will be used as sources of variability for the plant breeder, allowing the selection with views to the improvement of the characters of interest, guaranteeing in the long term the quality, in relation to the germinative capacity and the vigor of the seed lots to be commercialized (Pedron et al., 2004).

The Pearson correlation coefficients (r) between the biometric characteristics and the physiological quality of seeds evaluated in the germination tests are shown in Table 4.

Pearson correlation coefficients ( $r$ ) showed positive and significant correlations between seed length and FM100S $(r=0.642)$ and TS $(r=0.627)$, indicating a certain influence of size on this characteristic. The LS, BS, and TS, as well as seed FM100S, presented 
Table 4. Estimates of correlations among biometric and quality traits of seed originating from different mother trees of Mimosa scabrella Benth. collected in the municipalities of Abelardo Luz, Chapadão do Lageado, Lages, and Três Barras, Santa Catarina state (Brazil).

\begin{tabular}{|c|c|c|c|c|c|c|c|c|c|}
\hline & LS & BS & TS & FM100S & \%GER & GVI & MDG & $\% \mathbf{P N}$ & LNS \\
\hline LS & $0.011^{\mathrm{ns}}$ & & & & & & & & \\
\hline BS & $0.374^{\mathrm{ns}}$ & $-0.096^{\mathrm{ns}}$ & & & & & & & \\
\hline FM100S & $0.642^{\star *}$ & $0.430^{\mathrm{ns}}$ & $0.627^{\star \star}$ & & & & & & \\
\hline \%GER & $-0.032^{\mathrm{ns}}$ & $-0.086^{\mathrm{ns}}$ & $0.177^{\mathrm{ns}}$ & $0.096^{\mathrm{ns}}$ & & & & & \\
\hline GVI & $-0.090^{\mathrm{ns}}$ & $-0.030^{\mathrm{ns}}$ & $0.129^{\mathrm{ns}}$ & $0.056^{\mathrm{ns}}$ & $0.924^{\star *}$ & & & & \\
\hline MDG & $-0.261^{\mathrm{ns}}$ & $-0.121^{\mathrm{ns}}$ & $-0.153^{\mathrm{ns}}$ & $-0.232^{\mathrm{ns}}$ & $-0.137^{\mathrm{ns}}$ & $-0.138^{\mathrm{ns}}$ & & & \\
\hline$\% \mathrm{PN}$ & $-0.045^{\mathrm{ns}}$ & $-0.060^{\mathrm{ns}}$ & $0.169^{\text {ns }}$ & $0.094^{\mathrm{ns}}$ & $0.977^{\star \star}$ & $0.926^{\star *}$ & $-0.105^{\mathrm{ns}}$ & & \\
\hline LNS & $-0.064^{\mathrm{ns}}$ & $-0.060^{\text {ns }}$ & $0.151^{\mathrm{ns}}$ & $0.101^{\mathrm{ns}}$ & $0.527^{\star}$ & $0.535^{\star}$ & $-0.051^{\mathrm{ns}}$ & $0.527^{\star}$ & \\
\hline DMS & $0.076^{\mathrm{ns}}$ & $-0.006^{\mathrm{ns}}$ & $0.230^{\mathrm{ns}}$ & $0.235^{\mathrm{ns}}$ & $0.909^{\star *}$ & $0.861^{* *}$ & $-0.130^{\text {ns }}$ & $0.917^{\star *}$ & $0.625^{\star *}$ \\
\hline
\end{tabular}

Length (LS); breadth (BS); thickness (TS) of seeds and fresh mass of 100 seeds (FM100S in g); Germination percentage (\%GER); germination velocity index (GVI); mean diary germination (MDG); percentage of normal seedlings (\%PN); length normal seedlings (LNS in $\mathrm{cm}$ ); and dry mass of the seedling (DMS in $\mathrm{g}) ;{ }^{\text {ns }}$ not significant $(\mathrm{p}>0.05)$; ${ }^{*}$ significant $(\mathrm{p} \leq 0.05)$; ${ }^{* *}$ significant $(\mathrm{p} \leq 0.01)$ by the test $\mathrm{F}$.

non-significant correlations with the characteristics evaluated in the germination test.

Similar results were obtained by Alves et al. (2005) and Santos et al. (2009), who did not find influence of the size of seeds of Mimosa caesalpiniifolia Benth. and T. chrysotricha Mart. ex. A. DC., respectively, on the characteristics coming from the germination test.

Studying the influence of seed provenance and size of M. scabrella, Sturion (1984) concluded that seed size does not affect the percentage of germination for most of the provenances evaluated for him. It can be suggested that for the species under study the biometric characteristics are not directly related to the physiological quality evaluated by the germination test, making it impossible to classify the seeds by size for the indirect selection of seeds with higher physiological quality.

Positive and high correlations were found between germination test characters, for example, between germination percentage and GVI $(r=0.924)$ and between this characters and the others characters coming from the germination test, except for the daily mean germination. These results indicate that seeds with a satisfactory germinative potential also express a higher performance, thus, the analysis of the variable germination percentage in an isolated way would serve to evaluate the germination potential and vigor of the seeds of $M$. scabrella, as well as for the reduction of the time and of the manpower expended in the quality analysis of a batch of seeds.

\section{CONCLUSIONS}

Based on the results obtained it is possible to conclude that:

- There is variation between the biometric characteristics of the seeds among the 40 mother trees analyzed;

- The characteristics evaluated in the test of germination demonstrate considerable variability in the physiological quality of the seeds between the mother trees of the same, and of different provenances;

- Overall, the mother trees of the provenances Abelardo Luz and Chapadão do Lageado obtained superior performance for the characteristics of the germination test;

- There is no correlation between the biometric characteristics and the germination test parameters for the evaluated M. scabrella seeds, making it impossible to use seed size as indicative of physiological quality seeds.

\section{ACKNOWLEDGEMENTS}

The authors are grateful to the Foundation for Research and Innovation of the State of Santa Catarina.

\section{SUBMISSION STATUS}

Received: 25 june, 2016

Accepted: 3 july, 2018 


\section{CORRESPONDENCE TO}

\section{Renata Diane Menegatti}

Programa de Pós-graduação em Fisiologia

Vegetal, Departamento de Botânica, Instituto

de Biologia, Universidade Federal de Pelotas

- UFPel, Campus Universitário, s/n, CP 345,

CEP 96010-900, Pelotas, RS, Brasil

e-mail: renata.d.menegatti@gmail.com

\section{FINANCIAL SUPPORT}

Fundação de Amparo à Pesquisa do Estado de Santa Catarina.

\section{REFERENCES}

Abud HF, Reis RGE, Teófilo EM. Caracterização morfológica de frutos, sementes, plântulas e germinação de Mucuna aterrima Piper \& Tracy. Ciência Agronômica 2009; 40(4): 563-569.

Alves EU, Bruno RLA, Oliveira AP, Alves AU, Alves AU, Paula RC. Influência do tamanho e da procedência de sementes Mimosa caesalpiniifolia Benth. sobre a germinação e vigor. Revista Árvore 2005; 29(6): 877-885. http://dx.doi.org/10.1590/S0100-67622005000600006.

Borém A, Miranda GV. Melhoramento de plantas. Viçosa: UFV; 2009.

Brasil. Ministério da Agricultura, Pecuária e Abastecimento. Instruções para análise de sementes de espécies florestais. Brasília: MAPA; 2013.

Carvalho NM, Nakagawa J. Sementes: ciência tecnologia e produção. 4. ed. Jaboticabal: FUNEP; 2000.

Carvalho PER. Espécies arbóreas brasileiras. Brasília: Embrapa Informação Tecnológica; 2003.

Figliolia MB. Colheita de sementes. In: Silva A, PiñaRodrigues, FCM, Figliolia MB. Manual técnico de sementes florestais. São Paulo: Instituto Florestal; 1995.

Freitas VLO, Alves THS, Lopes RMF, Lemos JP Fo. Biometria de frutos e sementes e germinação de sementes de Dimorphandra mollis Benth. e Dimorphandra wilsonii Rizz. (Fabaceae-Caesalpinioideae). Revista Scientia Florestalis 2009; 37(81): 27-35.

Friederichs G, Brand MA, Carvalho AF, Küster LC. Qualidade da madeira e do carvão vegetal de bracatinga (Mimosa scabrella Benth.). Brazilian Journal of Wood Science 2015; 6(2): 79-87. http://dx.doi.org/10.12953/2177-6830/ rcm.v6n2p79-87.

Guollo K, Menegatti RD, Debastiani AB, Posseti JC, Navroski MC. Biometria de frutos e sementes e determinação da curva de embebição em sementes de Mimosa scabrella Benth. Revista Cultivando O Saber 2016; 9: 1-10.

Lopes RMF, Freitas VLO, Lemos JP Fo. Biometria de frutos e sementes e germinação de Plathymenia reticulata Benth. e Plathymenia foliolosa Benth. (Fabaceae - Mimosoideae). Revista Árvore 2010; 34(5): 797-805. http://dx.doi. org/10.1590/S0100-67622010000500005.

Mazuchowski JZ, Angelo AC. Caracterização e entraves do sistema de produção com bracatinga na região metropolitana de Curitiba. Revista Floresta 2012; 42(4): 711-724. http://dx.doi.org/10.5380/rf.v42i4.17698.

Mazuchowski JZ, Rech TD, Toresan L. Bracatinga, Mimosa scabrella Bentham: cultivo, manejo e usos da espécie. 1. ed. Florianópolis: Epagri; 2014.

Menegatti RD, Mantovani A, Navroski MC, Guollo K, Vargas OF, Souza AG. Germinação de sementes de Mimosa scabrella Benth. submetidas a diferentes condições de temperatura, armazenamento e tratamentos pré-germinativos. Revista de Ciências Agrárias 2017; 40: 305-310.

Moreira PA, Steenbock W, Peroni N, Reis MS. Genetic diversity and mating system of bracatinga (Mimosa scabrella) in a re-emergent agroforestry system in Southern Brazil. Agroforestry Systems 2011; 83(2): 245-256. http://dx.doi. org/10.1007/s10457-011-9428-X.

Nogueira FCB, Medeiros S Fo, Gallão MI. Caracterização da germinação e morfologia de frutos, sementes e plântulas de Dalbergia cearensis Ducke (pau-violeta) - Fabaceae. Acta Botanica Brasílica 2010; 24(4): 978-985. http://dx.doi. org/10.1590/S0102-33062010000400013.

Oliveira-Bento SRS, Torres SB, Oliveira FN, Paiva EP, Bento DAV. Biometria de frutos e sementes e germinação de Calotropis procera Aiton W.T. Aiton (Apocynaceae). Bioscience Journal 2013; 29(5): 1194-1205.

Pedron FA, Menezes JP, Menezes NL. Parâmetros biométricos de fruto, endocarpo e semente de butiazeiro. Revista Científica Rural 2004; 34(2): 585-586. http://dx.doi. org/10.1590/S0103-84782004000200040.

Popinigis F. Fisiologia da semente. 2. ed. Brasília: AGIPLAN; 1985.

Sánchez FJZ, Lozano JLR, Carrillo JOAC. Evaluación financiera y de riesgo de una plantación forestal comercial en Zihuateutla, Puebla. Chapingo Serie Ciencias Forestales $y$ del Ambiente 2010; 16(1): 69-78.

Santos FS, Paula RC, Valadares J. Biometria e qualidade fisiológica de sementes de diferentes matrizes de Tabebuia chrysotricha (Mart. Ex A. DC.) Stand. Revista Scientia Forestalis 2009; 37(82): 163-173.

Sebbenn AM. Sistemas de reprodução em espécies tropicais e suas implicações para a seleção de árvores matrizes para reflorestamentos ambientais. In: Higa AR, Silva LD, editors. Pomar de sementes de espécies florestais nativas. Curitiba: FUPEF do Paraná; 2006. 
Silva MS, Borges EEL, Leite HG, Corte VB. Biometria de frutos e sementes de Melanoxylon brauna Schott (Fabaceae Caesalpinioideae). Revista Ceres 2013; 19(3): 517-524. http://dx.doi.org/10.1590/S0104-77602013000300020.

Sobierajski GR, Kageyama PY, Sebbenn AM. Sistema de reprodução em nove populações de Mimosa scabrella Bentham (Leguminosaceae). Revista Scientia Forestalis 2006; 71: 37-49.
Sturion JA. Influência da procedência e do tamanho de sementes de Mimosa scabrella Benth., na sobrevivência e crescimento de mudas no viveiro e após o plantio [dissertação]. Curitiba: Universidade Federal do Paraná; 1984.

Valadares J, Paula RC, Vitti Moro V. Germinação, desenvolvimento de plântulas e teste de tetrazólio em Poecilanthe parviflora Bentham (Fabaceae - Faboideae). Revista Científica 2009; 37(1): 39-47. 